$\begin{array}{lll}\text { KULTURA } & \begin{array}{l}\text { POLSKA A KADEMIA NAUK } \\ \text { KOMITET SOCJOLOGII }\end{array} & \text { ISSN 0023-5172 } \\ \text { i } & \begin{array}{l}\text { INSTYTUT STUDIÓW POLITYCZNYCH } \\ \text { SPOLECLENSTWO }\end{array} & \\ \text { 2011, nr 2-3 SOCJOLOGIA KULTURY } & \end{array}$

VICTORIA DUNAEVA

Uniwersytet Warszawski

\title{
BADANIE KULTURY W PRL I ZSRR ORAZ NOWE SPOJRZENIE NA KULTURE W POLSKIEJ I ROSYJSKIEJ SOCJOLOGII PO PRZEŁOMIE USTROJOWYM
}

\section{SOCJOLOGIA KULTURY W PRL I NOWA WIZJA KULTURY WSPÓŁCZEŚNIE}

Uniformizacja kultury w czasach PRL-u oznaczała ujednolicenie podaży dóbr kultury, demokratyzację dostępu do nich, prowadzenie celowej działalności upowszechniającej. Miało to niewątpliwie wpływ na stan badań nad kulturą. W pracach socjologicznych kultura przedstawiana była wówczas przede wszystkim jako „system instytucji”, które tworzą właściwe sobie treści i upowszechniają je odpowiednimi środkami w kręgach określanych jako „publiczność” czy „audytoria”. W PRL-u bowiem istniał jednolity system kultury, na co wskazuje analiza statystyki kulturalnej, analizy instytucjonalne oraz wyniki badań zbiorowości wiejskich. Z tego wynikała pełna „uniformizacja uczestnictwa w kulturze, a zarazem stylu życia, sposobu myślenia, pojmowania i przeżywania świata" (zob. Tyszka 1971, s. 54).

Podstawowym zadaniem socjologii kultury w PRL-u była kontrola stanu zaawansowania procesów upowszechnienia kultury oraz badanie różnorodnych form uczestnictwa. Analizując w latach siedemdziesiątych uczestnictwo w kulturze Andrzej Tyszka zwrócil jednak uwagę, że polega ono także na indywidualnym udziale w zjawiskach kultury, w wyniku czego następuje przyswajanie jej treści, używanie jej dóbr, podleganie jej normom i wzorom, a także tworzenie nowych jej wartości oraz odtwarzanie i przetwarzanie istniejących. W swojej znanej książce Uczestnictwo $w$ kulturze Tyszka wyraził przekonanie, że chociaż system kultury to nie suma ,indywidualnych sytuacji kulturalnych poszczególnych osób", nie sposób tych sytuacji pominąć, zwłaszcza dążąc do pełnej wiedzy na temat tego systemu. Jego zdaniem, starania socjologów, by badać wyłącznie cechy zbiorowe systemu kultury, doprowadzą do „istotnego uszczuplenia

Adres do korespondencji: vdunaeva@yahoo.com 
wiedzy o kulturze”. „Nawet masowe procesy kultury realizują się w sferze świadomości jednostkowej" - twierdził Tyszka (1971, s. 54). W latach siedemdziesiątych był jednym z nielicznych polskich socjologów, którzy odważyli się otwarcie mówić o tym, że wiedza o jednostkowym uczestnictwie w kulturze jest bardzo istotna, a dane statystyczne nie są w stanie jej dostarczyć.

Pewnym przełomem w rozumieniu mechanizmu przekazu i odbioru kulturalnego stało się także wydanie w 1972 r. książki Bogusława Sułkowskiego Powieść $i$ czytelnicy. Społeczne warunkowanie zjawisk odbioru. W PRL-u polityka kulturalna de facto wywierała decydujący wpływ na wybór do publikacji pozycji beletrystycznych, a wydawca kierował się ambicją wychowania społeczeństwa przez literaturę wartościową społecznie, jednak Sułkowski (1972, s. 205) doszedł do wniosku, że „bezceremonialne odnoszenie życiowego utylitaryzmu do sztuki zakłóca i wulgaryzuje subtelny proces komunikowania wartości artystycznych". Socjolog ten dokonał analizy bardzo odważnej dla czasów całkowitej kontroli procesów kulturowych: zademonstrował inne podejście do uczestnictwa kulturalnego - od strony relacji między odbiorcą a dziełem literackim jako komunikatem. Zwrócił uwagę na to, że w centrum analizy badaczy powinno się znaleźć następujące zagadnienie: Jak jest czytana literatura? Interesowało go bowiem wnikanie $\mathrm{w}$ istotę stosunku pomiędzy czytelnikiem a książką.

Należy zaznaczyć, że w centrum uwagi socjologów polskich w latach sześćdziesiątych i siedemdziesiątych znalazło się pojęcie kultury masowej. Antonina Kłoskowska (1964) kulturę masową określiła jako zjawisko współczesnego przekazywania wielkim masom odbiorców identycznych lub analogicznych treści płynących z nielicznych źródeł. Jej zdaniem, była to odpowiedź na realnie istniejącą potrzebę społeczną - potrzebę wyrwania się z codziennego życia i pracy. W latach sześćdziesiątych Kłoskowska należała do nielicznych obrońców kultury masowej, nie zgadzała się z tymi, którzy proponowali ignorowanie tego rodzaju kultury, widząc w niej tylko cechy negatywne, na przykład komercjalizację. Sądziła, że dla tamtych czasów oznaczałoby to odcięcie od kultury Zachodu i zniewolenie. Należy wziąć pod uwagę, że podstawowym wyróżnikiem modelu kultury za czasów PRL-u było „wychowanie nowego człowieka”, według którego wytwory kultury nie mogą być uważane za towar konsumpcyjny.

Warto podkreślić, że socjolodzy kultury w owym czasie zwracali szczególną uwagę na odbiór kultury popularnej w świetle jej wychowawczej roli. Zastanawiali się, w jakim stopniu środki masowego przekazu muszą się liczyć z oczekiwaniami odbiorców, jakie powinno być uczestnictwo w kulturze oraz jak należy interpretować zapotrzebowanie społeczne na rozrywkowe formy sztuki. W latach siedemdziesiątych istniało kilka odmiennych stanowisk. Jedno z nich polegało na uznaniu trafności koncepcji kultury masowej także w warunkach rzeczywistości socjalistycznej, bez podkreślenia odmiennej jakości treści „kapitalistycznych” i „socjalistycznych” tej kultury. Inni badacze uznawali, że kon- 
cepcji kultury masowej nie można przenieść na grunt socjalistyczny. Tomasz Goban-Klas (1972, s. 97) opisuje takie stanowisko w sposób następujący: „Pojęcie kultury masowej [...] tak dalece odchodzi od koncepcji antropologicznych kultury, że stało się konieczne powołanie nowej dyscypliny, specjalnie desygnowanej dla badania kultury masowej. Zadanie to podjęła socjologia kultury, która w rzeczywistości jest przede wszystkim socjologią kultury masowej".

Wielu socjologów, wśród nich Marcin Czerwiński, w drugiej połowie lat siedemdziesiątych zaczęło poważnie zastanawiać się nad kierunkami rozwoju socjologii kultury i jej funkcjami. Już wcześniej zarzucał on socjologii kultury, że się zamknęła $\mathrm{w}$ odrębnym przedziale instytucjonalnym, zdystansowała od antropologii kulturowej i teorii poszczególnych dziedzin kultury, że odwraca się od sposobów myślenia i dyscyplin, które mogłyby jej dostarczyć heurystycznie bogatych punktów wyjścia (Czerwiński 1965). Krytykując socjologię kultury za podejście do wyników badań, Marcin Czerwiński (1985, s. 83-84) określił ją jako dyscyplinę, która wybrała „ambicję pewności”. Wzrostowi pewności wiedzy uzyskanej towarzyszy „zmniejszenie się zawartości informacyjnej”. Pewność więc socjologia kultury opłaciła spadkiem siły informacyjnej. $Z$ tego punktu widzenia, według niego, najlepszym rozwiązaniem byłoby badać kulturę w duchu antropologii.

Nad rozwojem socjologii kultury zastanawiała się także Antonina Kłoskowska. W książce Socjologia kultury, wydanej po raz pierwszy w 1981 r., dokonała oryginalnej syntezy zagadnień podejmowanych przez socjologów kultury i spróbowała wytyczyć granice tej subdyscypliny. Praca ta stała się nie tylko obowiązkową lekturą na wszystkich kierunkach studiów socjologicznych w Polsce, ale również źródłem nowych inspiracji i nawiązań dla innych socjologów. Kłoskowska (1981, s. 13) zwracała szczególną uwagę na złożoność pojęcia socjologii kultury: „Trudności określenia socjologii kultury wynikają przede wszystkim z niejednoznaczności samego pojęcia kultury, z jego szerokiego i niejednorodnego zakresu, ze szczególnego nasilenia postaw wartościujących odnoszących się do zjawisk objętych tym pojęciem oraz z różnorodności tych postaw".

Należy przyznać, że socjologia kultury w PRL-u często stawała na rozdrożu. $Z$ dzisiejszego punktu widzenia można stwierdzić, że w znacznej mierze wynikało to $z$ faktu, że za swoje główne zadanie uznawała badanie upowszechnienia kultury, co nie wystarczało do zrozumienia i interpretacji wszystkich procesów kulturowych i społecznych.

Po przełomie ustrojowym socjolodzy polscy nieco inaczej zaczęli postrzegać temat upowszechnienia kultury. Na przykład Dzierżymir Jankowski (1991) przez upowszechnianie kultury rozumie intencjonalnie organizowane oddziaływanie służące kształtowaniu, rozwijaniu potrzeb i zainteresowań kulturalnych oraz stymulowaniu i wspomaganiu jednostek i małych grup społecznych do rozwijania i sublimacji swojej aktywności kulturalnej (recepcyjnej, współtwórczej i twórczej, zabawowej i rekreacyjnej). Z kolei Tadeusz Aleksander (1992, s. 101) uważa, że upowszechnianie kultury to rozkrzewianie i propago- 
wanie wartości po to, aby znalazły się one w zasięgu odbiorców i zostały przez nich przyjęte jako własne oraz pozostawiły po sobie w ich osobowości pozytywny ślad. W codziennej praktyce wychowania i kształcenia dorosłych upowszechnianie kultury to popularyzowanie takich elementów, jak: literatura, teatr, taniec, plastyka, śpiew, malarstwo, rzeźba, grafika, rysunek, rzemiosło artystyczne, architektura, obyczajowość, sport i rekreacja.

Przemiany dokonujące się w Polsce po roku 1989 doprowadziły do wyklarowania się nowego modelu życia kulturalnego.

Jak pisze Izabella Bukraba-Rylska (2004, s. 97): „O ile w okresie PRL-u ideologiczne założenia uformowały totalitarny model kultury, charakteryzujący się nie tylko nadrzędną pozycją nadawcy, jednokierunkową transmisją, ale również jednolicową, uznawaną za jedynie prawomocną ofertę, o tyle obecnie zarysowały się możliwości samodzielnego kształtowania przez różne grupy odpowiadającego im repertuaru, a więc rozwijania wielu równoprawnych porządków i wartości”. Bukraba-Rylska podkreśla, że oznacza to zamianę formuły „uczestnictwa”, innymi słowy biernego odbioru upowszechnionych treści, na formułę „lokalizmu” pojmowanego jako swobodne tworzenie dla danego środowiska i jego siłami takiej oferty, na jaką je stać.

Izabella Bukraba-Rylska (2004) zwraca też uwagę na to, że radykalna zmiana sytuacji stawia wyzwania nie tylko przed lokalnymi społecznościami, lecz także przed badaczami chcącymi opisywać nową rzeczywistość. Dotyczy to przede wszystkim aparatury pojęciowej oraz stosowanych narzędzi badawczych. Stawia zasadnicze pytanie, czy socjologia kultury dostosowana do kultury, charakteryzowanej przez Sułkowskiego (1995) jako skrajnie instytucjonalna, biurokratyczna, cenzurowana i podawana kontroli państwa, sprosta swemu zadaniu w konfrontacji z bogactwem rzeczywistości, czyli, jak pisze Aldona Jawłowska (1993, s. 47-48), wielością „lokalnych porządków zróżnicowanych według kryteriów środowiskowych, ekonomicznych, etnicznych i innych". Bukraba-Rylska przypuszcza, że zastąpienie modelu „uczestnictwa” modelem „lokalizmu” oznacza, że „nauka, która do tej pory zajmowała się odbiorem kultury, staje przed zjawiskiem nowym - musi analizować procesy polegające na tworzeniu oferty kulturalnej".

O zmianie modelu kultury w Polsce po roku 1989 pisze Krystyna Milczarek (1997). Zaznacza, że w PRL-u w centrum uwagi badaczy uczestnictwa w kulturze był model „kultury upowszechnionej” i szeroko dostępnej, po przełomie ustrojowym zaś dla socjologów zasadniczym stało się pytanie, „czy możliwa i dostępna jest nowa polityka kulturalna, uwzględniająca zmiany, jakie się dokonały". Milczarek twierdzi - sięgając do wcześniejszych ustaleń Andrzeja Tyszki - że ze względu na dotychczasowy stereotyp publiczności kultury ,jako publiczności odbiorców” udział w kulturze postrzegany był „tylko lub głównie pod kątem sprawności komunikowania odbiorcom zaprogramowanych treści". Negatywne rezultaty takiej polityki w rozumieniu Milczarek to: „wyuczona bezradność” oraz frustracja spo- 
łeczna. Blokują one lokalne inicjatywy, a także osłabiają lokalną tożsamość. Badaczka uważa, że w miarę stabilizowania się życia społecznego na nowych zasadach pojawi się szansa odbudowania związku między pozycją społeczną a uczestnictwem w kulturze, co będzie możliwe „dzięki innym, normalnym mechanizmom społecznym" Odpowiedzialność państwa zaś przesunie się ku „optymalnej edukacji kulturalnej”. Krystyna Milczarek (1997) wskazuje, że po przełomie ustrojowym w społeczeństwie polskim możliwe są różne formy uczestnictwa i nie ma zasadniczych przeszkód, poza ograniczeniami finansowymi i motywacyjnymi, w przejawianiu samodzielności i kreatywności kulturalnej.

Należy zaznaczyć, że socjolodzy polscy w latach dziewięćdziesiątych zaczęli zwracać szczególną uwagę na rolę animacji kulturalnej w utrwalaniu w społeczeństwie pewnej strategii działania. Coraz częściej zaczęto używać w związku $z$ animacją pojęcia kapitału społecznego oraz społeczeństwa obywatelskiego. Jak wiadomo, w okresie PRL-u istniał centralnie rozbudowany system instytucji państwowych odpowiedzialnych za zaspokojenie potrzeb kulturalnych oraz realizowanie polityki kulturalnej państwa. Rok 1989 — jak czytamy w książce Ośrodek Kultury i Aktywności Lokalnej (Mołda, Skrzypczak 2003) - przyniósł instytucjom kultury, w tym domom kultury, ostrą falę krytyki, która kwestionowała potrzebę ich istnienia, przedstawiano je jako symbol propagandy i ideologicznego oddziaływania na społeczeństwo. Autorzy zaznaczają, że po przemianach ustrojowych przetrwały i nabrały innego znaczenia takie instytucje kulturalne, które $z$ jednej strony dostosowały się do nowych samorządowych realiów, a z drugiej — za jedno ze swoich głównych zadań uznały rozbudzenie aktywności społeczności lokalnych, budowanie autentycznej wspólnoty lokalnej poprzez wspólne działania. O tym szczegółowo piszą również Jan Grad i Urszula Kaczmarek w książce Organizacja $i$ upowszechnianie kultury w Polsce. Zmiany modelu (1999). Rozpatrując nowe podejście do uczestnictwa w kulturze, autorzy sięgają do modeli europejskich i nowe rozwiązania widzą $w$ aktywizacji społeczeństwa, w animacji społeczno-kulturalnej.

Nad nową wizją kultury po przełomie ustrojowym zastanawia się między innymi Wojciech Józef Burszta. W ślad za Jeremym Rifkinem i Antoniem Negri uznaje, że w świecie nowoczesności trzeba patrzeć na kulturę jak na zasób albo na źródło praktycznych korzyści. W obronie takiego podejścia zwraca uwagę, że oparta na nim jest idea muzeów albo galerii sztuki. Podkreśla, że z zasobów kultury korzystają organizacje lokalne, rodzące się inicjatywy artystyczne, stowarzyszenia i animatorzy kultury. W tym kontekście, według Burszty, kultura-jako-zasób jest jedynie pretekstem dla działań edukacyjnych, artystycznych i kulturalnych, które "przekształcają ją w nową wartość, wynikającą z aktywności działających osób i grup" (Burszta 2008, s. 153).

Wielce interesująca pod względem nowej wizji kultury jest także książka Zygmunta Baumana Ponowoczesność jako źródło cierpień (2004). Analizując wiel- 
kie zmiany kulturowe nowoczesnego świata, który oferuje ekspansję wolności osobistej, socjolog zastanawia się nad funkcjami kultury. Za jej główne zadanie uznaje "utrzymanie ładu, w wojnie z żywiołowością i tym chaosem, co się z żywiołowości poczyna". W wojnie ładu z żywiołem - twierdzi socjolog - kultura staje bez wahania po stronie ładu. Podkreśla, że $\mathrm{w}$ epoce nowoczesności socjolodzy powinny opracować nową wizję kultury, całkiem odmienną od tej, która zastygła w tradycyjnym paradygmacie. Zastanawiając nad tym, jaka powinna ona być, używa określenia metaforycznego: „cała w ruchu, płynna i rozpływająca się, porządkująca może, ale sama nie uporządkowana, mniej od poprzedniej wizji zachęcająca, bo nie dająca nadziei na portret ostateczny, skończenie miarodajny, autorytatywny" (Bauman 2004, s. 187). Zaznacza, że chodzi nawet nie tyle o wizję kultury, ile raczej o sposób jej kreślenia; w nowych uwarunkowaniach społecznych ważna jest informacja nie o tym, czym kultura jest, ale o tym, jak się ona dzieje.

Konkludując - socjologia kultury w Polsce po przełomie ustrojowym stanęła przed wyzwaniem uchwycenia wszystkich istotnych kierunków zmian i zarazem wskazania nowego modelu społeczno-kulturowego.

\section{BADANIE KULTURY W ZSRR I NOWE DROGI SOCJOLOGII KULTURY WE WSPÓŁCZESNEJ ROSJI}

Partia Komunistyczna Związku Radzieckiego przywiązywała dużą wagę do roli kultury, która była jednym z narzędzi kształtowania świadomości mas. W ZSRR w latach pięćdziesiątych zaczęły licznie powstawać ludowe uniwersytety kultury, amatorskie teatry, kluby i pałace kultury, upowszechniano i promowano czytelnictwo. W centrum uwagi władzy znajdowały się także badania kultury, które miały potwierdzać tezę o szybkim kulturalnym rozwoju mas. Tak jak w Polsce kultura przedstawiana była przede wszystkim jako system instytucji.

W socjologii radzieckiej jednostkowa determinanta procesów społecznych mogła być rozpatrywana wyłącznie w ramach paradygmatu Karola Marksa: „osobowość jest zespołem relacji społecznych”. W socjologii radzieckiej, podobnie jak w zachodniej, uznawano, że społeczeństwo dominuje nad osobowością. Jeżeli jednak zgodnie $z$ tradycją zachodnią, wywodzącą się choćby od Émile'a Durkheima (zob. Fabiś 2008), pojęcie „społeczeństwo” jest związane z pojęciem „kultura”, to w ZSRR było ono skojarzone wyłącznie z państwem. Socjologia sowiecka mogła funkcjonować tylko w zgodzie $z$ marksistowskim paradygmatem, według którego kultura jest nadbudową nad ekonomiczną bazą, a osobowość jest produktem relacji społeczno-ekonomicznych.

Nie sposób zapomnieć, że byli też badacze o odmiennych poglądach, którzy dostrzegli oczywistą niezgodność między oficjalną doktryną o kulturalnym 
rozkwicie w „najbardziej czytającym kraju świata” ${ }^{1}$ a rzeczywistością, w której istniały i duże zróżnicowania typologicznych grup konsumentów produktów kultury, i underground, i obywatele-telewidzowie, i elita kulturalna o charakterze liberalno-demokratycznym. Pisał o tym między innymi socjolog Władimir Jadow (1998). Inna rzecz, że władza sowiecka nie była zainteresowana tymi badaniami i nie zostały one przeprowadzone w odpowiedni sposób. Nie można jednak zaprzeczyć, że to właśnie tym naukowcom w znacznym stopniu należy zawdzięczać rozwój rosyjskiej socjologii kultury. Władimir Jadow proponuje zwrócić uwagę na badania przeprowadzone przez socjologów radzieckich w drugiej połowie lat sześćdziesiątych. Sowiecka socjologia kultury odrodziła się w okresie „odwilży” jako specjalny rodzaj badań działalności instytucji kultury. Badania te prowadzono w ramach nie tyle paradygmatu marksistowskiego, ile paradygmatu komunikacji kulturalnej. Socjologów interesowało między innymi, kto produkuje kulturalny „produkt”, w jaki sposób on się rozpowszechnia, jak jest odbierany przez ludność. Należy podkreślić, że socjolodzy radzieccy tworzyli bardzo zwartą społeczność, w której odgrywali istotną rolę także naukowcy $z$ różnych republik radzieckich, na przykład z Ukrainy i Białorusi.

Ważne znaczenie dla rozwoju socjologii kultury w ZSRR miała „szkoła Siergieja Płotnikowa". W 1968 r. pod jego redakcją została wydana książka Czetowiek $i$ iskusstwo, obok analizy obszernych badań empirycznych zawierająca próbę przedstawienia tematu w kategoriach socjologii teoretycznej. Autorzy tej książki de facto polemizowali ze strukturalistycznymi przedstawicielami funkcjonalizmu, tym samym motywując czytelnika do refleksji metodologicznej. W podobnym duchu zostało wydanych siedem tomów rocznika „Socyołogija kultury", w tym kilka poświęconych empirycznym metodom badania kultury. Te działania nabierają większego znaczenia, gdy przypomnimy sobie, że na początku lat sześćdziesiątych w naukach humanistycznych Związku Radzieckiego dominowało tzw. podejście instytucjonalne i w centrum uwagi socjologów kultury znajdowały się dane statystyczne dotyczące odwiedzania teatrów, koncertów, kin, klubów, bibliotek. Najważniejszy był czynnik ilościowy, istniała nawet niejawna zasada: „im więcej, tym lepiej”. Ignorowano przy tym całkowicie samodzielną twórczość kulturalną. Według oficjalnej doktryny naukowej pod uwagę należało brać tylko klubowe przejawy twórczości amatorskiej. Pod koniec lat sześćdziesiątych podejście instytucjonalne zaczęło być zastępowane „podejściem do osobowości”: socjolodzy zwrócili uwagę na zainteresowania i potrzeby kulturalne odbiorców kultury, przestając postrzegać ich jako nieokreśloną masę. „Szkoła Płotnikowa”, która opierała się na najnowszych osiągnięciach zachodniej socjologii kultury, odegrała dużą rolę w utrwalaniu tego nowego podejścia.

1 To stwierdzenie, wypowiedziane przez generalnego sekretarza Partii Komunistycznej ZSRR Leonida Breżniewa na jednym z partyjnych zjazdów, było szeroko promowane i sprzyjało propagandzie czytelnictwa. 
Analizując postępy rozwoju socjologii kultury w ZSRR, należy także wspomnieć nazwisko socjologa Jurija Dawydowa. W latach sześćdziesiątych był on jednym $z$ niewielu promujących $w$ środowisku socjologicznym Związku Radzieckiego idee filozofów i socjologów zachodnich. W warunkach reżimu opartego na ,jedynej prawdziwej ideologii” był to najskuteczniejszy sposób wprowadzenia lokalnej nauki do światowej tradycji socjologicznej. Duży wkład Jurija Dawydowa w poszerzenie horyzontów radzieckiej socjologii kultury polegał również na tym, że badając rolę socjokulturalnych czynników w rozwoju filozofii i sztuki, nieustannie walczył $z$ „wulgarnym socjologizmem” ${ }^{2}$. Promował idee obce oficjalnej ideologii, między innymi twierdził, że szuka jest „zjawiskiem socjologicznym” i należy ją rozpatrywać nie jako „narzędzie ideologiczne”, lecz w kontekście jej odbioru przez publiczność, zwracając uwagę na rozmaite warstwy i grupy społeczne (Dawydow 1971). Interesowało go także, w jakim stopniu sztuka jest zdolna motywować społeczność do działań wynikających z refleksji nad poszczególnymi stanami rzeczy. W dziedzinie socjologii kultury był to bardzo ważny projekt, ale i niełatwe zadanie - socjolog powinien przekonać doń swoich kolegów, myślących przeważnie w kategoriach marksistowskich, Jurij Dawydow musiał jednak z niego zrezygnować. Nie tylko z powodu przeszkód, jakie władza stawiała przed takiego rodzaju niepożądanymi badaniami, lecz dlatego, że rozumiał, iż jego propozycja przeanalizowania pedagogicznego znaczenia sztuki $\mathrm{w}$ czasach radzieckich mogła być potraktowana zbyt „wulgarnie”.

Rezygnacja ta nie oznaczała końca badań Jurija Dawydowa nad rolą kultury i sztuki. Na początku lat siedemdziesiątych zaczął pracować nad innym dużym projektem, który wiązał się $z$ ostatecznym odejściem od neomarksizmu i „renesansowego rozumienia człowieka”. Głównym zadaniem stało się dla Jurija Dawydowa opracowanie nowej koncepcji kultury, która miała służyć badaniu fundamentalnych warunków istnienia ludzkiego. W latach dziewięćdziesiątych skoncentrował się jednak na formowaniu rosyjskiej interpretacji socjologii teoretycznej ${ }^{3}$, w związku z czym to pierwsze zadanie - jak pisze Aleksander Filipow (2007), wspominając Jurija Dawydowa po jego śmierci ${ }^{4}$ zostawił socjologom współczesnym.

W czasach radzieckich Jurij Dawydow był naukowcem skutecznym: profesorem, kierownikiem wydziału Instytutu Socjologii Akademii Nauk, jego książki drukowały prestiżowe wydawnictwa. Był on - jak pisze Filipow - specjalistą, którego zwierzchnictwo bardzo ceniło, chociaż uważało za „podejrzanego”. $\mathrm{W}$ środowisku inteligencji humanistycznej był jednym $z$ prawdziwych autorytetów. Z jego nazwiskiem kojarzyły się nowe możliwości rozumienia Hegla

\footnotetext{
2 Jest to synonim dogmatycznej filozofii marksistowskiej.

${ }^{3}$ Jurij Dawydow utworzył wydział historii i teorii socjologii w Rosyjskiej Akademii Nauk i przez wiele lat nim kierował.

4 Jurij Dawydow zmarł 21 kwietnia 2007.
} 
i Maksa Webera, kształtowanie socjologii teoretycznej, a także próby nowego spojrzenia na kulturę poprzez jej oddziaływanie na aktywność obywateli ${ }^{5}$.

Jednak pod koniec lat siedemdziesiątych „socjologiczny boom” w Związku Radzieckim nagle się skończył. Większość wyników badań socjologicznych, w tym dotyczących kultury, nie była użyteczna dla władz radzieckich, które potrzebowały prac potwierdzających tezę, że ZSRR jest najbardziej wykształconym i kulturalnym krajem. Wyniki badań empirycznych $z$ tą tezą często się nie zgadzały i socjolodzy musieli przerywać swoje prace.

W epoce breżniewowskiej, zwanej „epoką zastoju”, zjawiska kulturalne były interpretowane jako przejaw aktywnej postawy człowieka w społeczeństwie. Rozwój kultury kojarzył się z „rozwojem człowieka jako istoty społecznej”. W konsekwencji twierdzono, że tylko komunizm jest zdolny do tego, by zapewnić „zbieżność rozwoju historycznego i kulturalnego” (Kogan 1998). Taki paradygmat był potrzebny ideologii państwowej w ZSRR w drugiej połowie lat siedemdziesiątych.

Szerokie upowszechnienie telewizji w latach siedemdziesiątych i osiemdziesiątych doprowadziło w ZSRR do radykalnych zmian w codziennej aktywności kulturalnej milionów ludzi. Telewizja stała się, jak twierdzi socjolog Lew Kogan (1998), centrum „życia duchowego” większości obywateli ZSRR. Środki masowego przekazu, wraz z państwowymi instytucjami kultury, wywierały decydujący wpływ na proces tworzenia masowych symboli kulturowych. Cała polityka kulturalna epoki Breżniewa sprowadzała się do twardego systemu kontroli środków masowego przekazu oraz repertuaru instytucji kultury obwarowanego zakazem jakichkolwiek odstępstw od norm. W tym czasie wyniki badań wielu socjologów wskazywały na istotną rozbieżność między zapotrzebowaniami kulturalnymi rozmaitych grup ludności a zideologizowaną państwową polityką kulturalną. Badania odnotowywały w tamtym czasie gwałtowny spadek uczestnictwa w instytucjach kultury, między innymi odwiedzania teatrów, muzeów, kin, klubów. Ograniczyła się też samodzielna twórczość amatorska.

Od drugiej połowy lat siedemdziesiątych do połowy lat osiemdziesiątych socjologia radziecka przeżywała stan kryzysu, który ujawnił się w okresie pierestrojki. W postradzieckiej Rosji socjolodzy zostali postawieni przed poważnym wyzwaniem: jak przejść od „jedynie prawdziwego” paradygmatu marksistowskiego do opanowania i zastosowania rozmaitych socjologicznych teorii i podejść funkcjonujących w socjologii światowej. Kluczową rolę pod tym względem odegrał Instytut Socjologii Akademii Nauk Związku Radzieckiego i jego dyrektor Władimir Jadow, który zaproponował i uzasadnił stosowanie wielu podejść teoretycznych jako główny kierunek ewolucji instytutu i socjo-

5 Dziś książki Dawydowa znowu nabierają znaczenia. Pojawiają się nowe wydania jego znanych dzieł: Robota i swoboda (1962), Iskusstwo i elita (1966), Sztuka jako zjawisko socjologiczne (1971 [1968]). Jego prace są włączone do obowiązkowych lektur w wyższych uczelniach Federacji Rosyjskiej, rosyjscy socjolodzy coraz częściej powołują się na nie w swoich debatach nad kulturą. 
logii rosyjskiej. Gorzej było z socjologią kultury. W pierwszej połowie lat dziewięćdziesiątych tematyka badań socjologicznych dotyczyła przede wszystkim politycznego i gospodarczego reformowania Rosji. W centrum zainteresowań socjologów znajdowały się tematy „pożądane” przez nowe władze: podział dochodów, relacje władzy i społeczeństwa, bieda, miejsce elit w społeczeństwie, sytuacja w regionach. Socjologia kultury nie była w stanie podjąć nowych tematów, gdyż potrzebowała nowego paradygmatu.

Warto zaznaczyć, że wydarzeniem istotnym dla procesu kształtowania rosyjskiej interpretacyjnej socjologii kultury było wydanie książki pod redakcją Jurija Lewady zatytułowanej Sowietskij prostoj czełowiek (1993). Powstała ona na podstawie szeroko zakrojonego badania przeprowadzonego przez wszechrosyjskie centum badania opinii społecznej jeszcze w listopadzie $1989 \mathrm{r}$. Na podstawie wyników tego badania autorzy książki przedstawili kulturowy wizerunek „prostego sowieckiego człowieka”. Wyróżnili jego cztery podstawowe cechy:

— przekonanie o własnej wyjątkowości: sowiecki człowiek jest niezwykły, posiada wyjątkowe wartości oraz sądy o prawdzie i pięknie;

— orientacja państwowo-paternalistyczna, której towarzyszy oczekiwanie „ojcowskiej opieki” ze strony państwa;

- gotowość do uznania każdego obowiązującego porządku i reżimu;

- nastawienie mocarstwowe według antynomicznego schematu: „narodowe-nienarodowe".

Wszystkie wymienione cechy — jak twierdzą autorzy przywoływanego zbioru (Lewada 1993) - świadczą raczej o przynależności człowieka do pewnego systemu ograniczeń niż o jego działaniach. Główną cechą wyróżniającą go jest przynależność do systemu społecznego, reżimu, gotowość do zaakceptowania go, a nie postawa aktywna.

Człowiek sowiecki z jednej strony jest nosicielem pewnych funkcjonalnych cech, a $z$ drugiej strony jest podmiotem lojalnym wobec hierarchicznie uporządkowanej władzy. W oparciu o tę tezę autorzy książki Sowietskij prostoj czełowiek sformułowali wniosek bardzo istotny, jak uważa socjolog Aleksander Sogomonow (1998), dla rozumienia procesu kształtowania postsowieckiej socjologii kultury.

„Ponieważ państwowa lojalność nie zawiera kryteriów efektywności, a osiągnięcia $\mathrm{w}$ pracy nie gwarantują statusu społecznego i nie są związane $z$ odpowiednim wynagrodzeniem i awansem społecznym, to w sednie systemu społeczeństwa radzieckiego (a także w mentalności sowieckiego człowieka) kryje się sprzeczność. Dlatego sowiecka rzeczywistość (oraz mentalność ludzi) jest fikcją, opartą na "demonstracji»" (Lewada 1993, s. 75).

Warto zaznaczyć, że pojęcie „prosty sowiecki człowiek” różni się od pojęcia "homo soveticus”, sformułowanego przez rosyjskiego pisarza i socjologa Aleksandra Zinowiewa (1986), w Polsce spopularyzowanego przez ks. Józefa Tischnera (1993). Jest to mające negatywny wydźwięk określenie człowieka 
przyzwyczajonego do komunistycznej formuły państwa, oczekującego, że od państwa otrzyma pracę, opiekę socjalną i zdrowotną. Pojęcie „prosty sowiecki człowiek" zaś obejmuje również istniejące w świadomości Rosjan pozytywne cechy „obywatela ZSRR”. Jest to pojęcie o charakterze kulturowym, określające pewien typ antropologiczny.

„Prosty sowiecki człowiek” uznaje taki porządek rzeczy, w którym w celu choćby częściowej realizacji prywatnych wartości musi zaakceptować wartości państwowe. Autorzy książki podkreślają, że takie kompromisy, zgubne dla osobowości, niszczą kryteria moralne stosunków społecznych i w konsekwencji samo społeczeństwo. Jak zaznacza Aleksander Sogomonow (1998), obecnie rosyjski system społeczny oparty jest na takiej samej zasadzie „zgody społecznej". Z tego wynika, że w postradzieckim społeczeństwie de facto nadal istnieje „Człowiek sowiecki”.

Taki wniosek nie został jednak jednomyślnie przyjęty przez współczesnych rosyjskich socjologów kultury. Jak sugeruje Sogomonow, z którym się zgadza Jadow, autorzy książki o prostym sowieckim człowieku poszli drogą zbytniej ontologizacji kodów symbolicznych i socjokulturowych archetypów, nie dostrzegając uniwersalnej natury współczesnego podmiotu. Doceniając znaczenie tego pierwszego niezależnego ideologicznie badania, którego wyniki były szeroko dostępne, zarówno Aleksander Sogomonow (1998), jak i Władimir Jadow (1998) wskazują, że socjolodzy rosyjscy powinni obecnie skupić się na opracowaniu uniwersalnych schematów teoretycznych, odpowiadających rosyjskiej historii i kulturze.

Należy przy tym zwrócić uwagę, że w rosyjskim środowisku naukowym można spotkać obecnie bardzo różne, niekiedy całkowicie przeciwstawne stanowiska co do możliwości rozwoju kulturalnego dzisiejszej Rosji.

Po upadku Związku Radzieckiego wydawało się, że publiczna twórcza samorealizacja nie napotyka w Federacji Rosyjskiej poważnych przeszkód: wydawane są bowiem książki i czasopisma, organizowane są wystawy, kręcone są filmy, powstaje wiele audycji telewizyjnych i spektakli na scenach amatorskich. Większość twórców nie ma do czynienia z jakimikolwiek przejawami cenzury państwowej. Jednak w środowisku socjologów coraz częściej powstaje pytanie: czy to, co teraz nazywa się kulturą współczesną, odpowiada pojęciu kultury w jej tradycyjnym rozumieniu? Socjolog kultury Borys Dubin (2008) twierdzi, że kultura w jej właściwym rozumieniu przeżywa dziś trudne czasy, a te zjawiska, które do niej często są błędnie zaliczane, świadczą raczej o dążeniu człowieka do dostosowania się do zmieniającej się sytuacji, niż o stworzeniu nowych kategorii znaczeniowych. Jeżeli natomiast — jak dalej pisze rosyjski uczony przyjąć tezę, że kultura to „całokształt sposobów i wyników ludzkiej działalności” lub „całokształt zasad i przedmiotów stworzonych przez ludzi”, to wydaje się, że nie istnieje powód, by kwestionować jej istnienie we współczesnej Rosji.

Trzeba jednak brać pod uwagę, że pozostałości kultury radzieckiej odgrywają swoją rolę w kształtowaniu świadomości współczesnego Rosjanina. Jurij 
Lewada nazywał tę kulturę „kulturą dyrektywną” albo „kulturą państwową”, a Borys Dubin (2008) proponuje określenie „kultura masowo-mobilizacyjna”. Po upadku Związku Radzieckiego ta kultura powinna była zniknąć, choć bowiem instytucje kultury zasadniczo się nie zmieniły, przekształcają się formy ich działalności, częściowo także podejście do odbiorcy, lecz proces ten jest dość wolny.

W opinii dyrektora Lewada-Centrum Lwa Gudkowa rozpad imperium nie naruszył wielu instytucji stanowiących dziś dla władzy główne oparcie. Wynika to ze słabości nowych elit, które nie są $\mathrm{w}$ stanie realizować prozachodniego kursu reform. Uderzające jest to, że w wyobrażeniach Rosjan, zwłaszcza przedstawicieli „pokolenia sowieckiego”, przeszłość jest wyidealizowanym uosobnieniem czasu spokoju, dostatku, stabilności, bezpieczeństwa. „Żyjemy szczątkami totalitaryzmu. Sam reżim się rozpadł, lecz znacząca część jego instytucji - wojsko, tajne służby, sądownictwo, szkolnictwo - pozostała nietknięta" pisze Gudkow (2004). Postsowiecka nostalgia nie ma jakichkolwiek podstaw politycznych lub kulturowych konsolidujących rosyjskie społeczeństwo. Elity kulturalne nadal uczestniczą $\mathrm{w}$ procesie poszukiwania rosyjskiej idei, rosyjskiego fundamentalizmu. Nie będąc w stanie stworzyć nowej idei, zwracają się ku starym kliszom dziewiętnastowiecznych przedstawicieli rosyjskiego konserwatyzmu oraz nurtów narodowo-mistycznych, odwołujących się do mitologicznych podstaw, które rosyjska wspólnota narodowa wykorzystuje, by tworzyć swój zamknięty świat.

Wydaje się zatem trafna propozycja sformułowana przez Borysa Dubina (2008) w rozważaniach na temat rzeczywistości społeczno-kulturalnej w postradzieckiej Rosji, by zastąpić pojęcie „kultura” pojęciem „układy komunikatywne". Jego zdaniem, w dzisiejszej Rosji funkcjonują bardzo różne środowiska społeczne, brakuje jedności pozwalającej mówić o wspólnych wartościach kulturowych narodu rosyjskiego. Nie istnieje obecnie w Rosji taka instytucja lub opiniotwórcza grupa, która mogłaby połączyć w całość wszystkie elementy znaczeniowe.

Wynika $z$ tego, że przed rosyjskimi socjologami kultury stoi zadanie niełatwe. Tradycyjne pojęcia, jak „kultura”, „sztuka”, „osobowość”, przestają odpowiadać nowo wprowadzanym treściom. W naukach humanistycznych i społecznych wyraźnie brakuje nowych pojęć, za pomocą których można byłoby opisać i wytłumaczyć rosyjską społeczno-kulturową rzeczywistość.

Należy zaznaczyć, iż w celu opisania społeczeństwa rosyjskiego i zachodzących w nim procesów kulturowych socjolodzy powoli próbują wprowadzać nowe określenia, takie jak „tożsamość negatywna” (Gudkow 2004), „nostalgia za czasami radzieckimi” (Lewada 2004), „alibi”, „kultura hedonistyczna” (Dubin 2008). Nadal jednak najważniejszym zadaniem socjologii kultury w Rosji, według Borysa Dubina, jest stworzenie kompleksowego projektu „kultura”, który służyłby sprecyzowaniu nowych pojęć. Zwraca on uwagę, że tożsamość człowieka kształtuje to, co tworzy on w teraźniejszości, myśląc o przyszłości. 
Jednak ponad połowa rosyjskiej ludności w roku 2007 nie umiała odpowiedzieć na pytanie o to, jak będzie wyglądała ich najbliższa przyszłość. Trzeba to potraktować jak problem kulturowy — twierdzi Dubin (2008). Zgadza się z nim także Lew Gudkow (2004), wyjaśniając, że główny problem Rosjan tkwi w ich autostereotypie i wyobrażeniu na temat otaczającej rzeczywistości, w strukturze akceptowanego przez nich świata znaczeń, wciąż narzucanych przez media i wiele oficjalnych instytucji.

Trudność zadania, jakie stoi przed rosyjskimi socjologami, potęguje fakt, że borykają się z problemami własnej identyfikacji.

Nieco inaczej postrzega zadanie współczesnej socjologii kultury wybitny rosyjski socjolog Władimir Jadow. Jak pisze w swojej książce o socjologii w Rosji (1998), postradziecka socjologia kultury dystansuje się od systemowo-strukturalnego paradygmatu i proponuje kulturalistyczną interpretację procesów społecznych. Za jej najbardziej mocną stronę, zdaniem tego uczonego, należy uznać dążenie do przemyślenia procesów historycznych w kontekście kultury. Rosyjscy socjolodzy kultury w teoretycznych rozważaniach skupiają się między innymi na takich pojęciach, jak „charakter narodowy Rosjan”, „prosty sowiecki człowiek”, „człowiek postradziecki”. Profesor Rosyjskiej Akademii Nauk Nikołaj Lapin uważa natomiast, że powinni zająć się stworzeniem wizerunku socjokulturowej przestrzeni Rosji: jej regionalnej dyferencjacji i uzasadnień jej całości. Badania w tym kierunku nie były prowadzone w odpowiedni sposób w ZSRR, a mogą stać się nowym kierunkiem rozwoju rosyjskiej socjologii kultury. Zdaniem Nikołaja Lapina, inspiracją zmian społeczno-kulturowych często stają się społeczności lokalne (Lapin, Beliajewa 2006).

Podsumujmy — rosyjska socjologia kultury ma obecnie wiele twarzy i musi podjąć próbę opracowania uniwersalnych schematów teoretycznych, opanowania „lingwistycznego zamieszania” oraz złożenia nowych dla niej koncepcji w integralną całość.

Po upadku reżimu komunistycznego i zasadniczych zmianach o charakterze politycznym, gospodarczym i społeczno-kulturowym socjologia kultury zarówno w Polsce, jak i w Rosji znalazła się w zupełnie nowej sytuacji. Znikły dyktat i ideowa kontrola państwa, które przez długi czas w obu krajach ograniczały wolność myśli naukowej, zwłaszcza w dziedzinie nauk społecznych i humanistycznych. Socjologia przestała być narzędziem spekulacji politycznych — jak za czasów radzieckich, stała się zaś nauką stricte empiryczną, która między innymi bada rzeczywistość stworzoną przez poszczególne grupy społeczne. Warto zaznaczyć, że w Federacji Rosyjskiej w okresie transformacji socjologia wreszcie została uznana za pełnowartościową i potrzebną dyscyplinę naukową. Zaczęto ją wykładać na wyższych uczelniach, pojawiły się samodzielne wydziały socjologii, została zaakceptowana obrona doktoratów z socjologii (w czasach 
ZSRR socjologię uważano za część filozofii). W Rosji podobnie jak w Polsce stały się dostępne tłumaczenia współczesnych prac uczonych zachodnich, co stworzyło grunt sprzyjający teoretycznemu i empirycznemu rozwojowi dyscypliny. Pojawiło się mnóstwo ośrodków analitycznych, które prowadzą badania dotyczące społeczeństwa nowego typu kształtującego się w okresie transformacji. Motywacją do nowych badań staje się sama postradziecka rzeczywistość, strukturalna i kulturowa transformacja społeczeństwa (Mateckaja, Samygin 2007, s. 77). Rośnie również zainteresowanie socjologicznymi badaniami kultury.

Jak już powiedziano, duże znaczenie dla przemyślenia sowieckiego dziedzictwa kulturowego w Rosji miało wydanie na początku lat dziewięćdziesiątych książki pod redakcją Juria Lewady Sowietskij prostoj czełowiek. Książka ta była wynikiem dogłębnych badań empirycznych typu człowieka, który się ukształtował w warunkach komunistycznego reżimu. Uważa się też, że w rozwoju współczesnej rosyjskiej socjologii kultury olbrzymią rolę odegrała podjęta przez Leonida Ionina próba sformułowania nowego określenia kultury. Ionin stwierdza (1995, s. 5-6): „W społeczeństwie zniknęła naiwna wiara w obiektywizm procesów społecznych, co oznacza, że społeczeństwo zasadniczo się zmienia. Zmiany te mają przede wszystkim charakter kulturowy". Zgodnie $z$ jego opinią, przemiany społeczne $\mathrm{w}$ większości wypadków mają „motywację kulturową", w okresie transformacji kultura w pewnym sensie staje się siłą napędową zmian społecznych, chociaż nie od razu jest to zauważalne. Podobną opinię wyraziło wielu polskich socjologów. Piotr Sztompka (2000) stwierdził, iż kultura w przemianach społecznych występuje w podwójnej roli — jako środek (poprzez kulturę zmieniamy) i produkt zmiany (kultura zmianie podlega). Znakomicie pisał o tym także Wojciech Józef Burszta (2008, s. 154): „Upatrywałbym nadziei na to, że przekształcenie kultury w zasoby, z których buduje się wyobraźnię, doznania i estetykę codzienności, nie do końca da się sprowadzić do rynku, zysku i metakulturowej gry o globalnym wymiarze, że kultura jest także źródłem budowania obywatelstwa kulturalnego".

Porównując tematy badań empirycznych w okresie transformacji w Polsce i Rosji, można dojść do wniosku o ich częściowym podobieństwie. W centrum uwagi rosyjskich socjologów, podobnie jak polskich, znajdują się: zmiany modelu wspólnoty społecznej oraz mentalności jednostek, nowe podziały społeczne, dynamika wartości, kultura masowa we wszystkich jej przejawach, środki masowego przekazu i ich wpływ na społeczeństwo, kryzys tożsamości, młodzieżowe subkultury itd. W Rosji po przełomie ustrojowym zaczęto też mówić w środowisku socjologów o zjawisku nacjonalizmu i ksenofobii oraz dialogu międzykulturowym.

Należy też podkreślić, że zarówno w Polsce, jak i w Rosji zauważalny jest obecnie „brak syntezy — zagadnienia wspólnotowości, więzi i integracji społecznej”, jak w 2007 r. na zjeździe socjologicznym stwierdził Piotr Gliński (2008, s. 27), podsumowując rozwój polskiej socjologii. 
Nie sposób nie zaznaczyć, że po przełomie ustrojowym socjologia rosyjska, $\mathrm{w}$ tym socjologia kultury, musiała nadrobić wiele lat pozostawania $\mathrm{w}$ podziemiu w latach sześćdziesiątych oraz wykorzystywania jej wyłącznie w celach propagandowych w okresie rządów Leonida Breżniewa. Dlatego w okresie transformacji tak istotne było poszukiwanie nowych dróg teoretycznych i empirycznych oraz sprecyzowanie pojęć dotyczących specyfiki systemu radzieckiego i społeczeństwa postsowieckiego, co niewątpliwie odróżnia rosyjską socjologię kultury od polskiej.

\section{BIBLIOGRAFIA}

Aleksander Tadeusz, 1992, Proces upowszechniania kultury, w: Jadwiga Włodek-Chronowska (red.), Szkoła w procesie przemian edukacyjnych, Uniwersytet Jagielloński, Kraków. Bauman Zygmunt, 2004, Ponowoczesność jako źródto cierpień, Sic!, Warszawa.

Bukraba-Rylska Izabella, 2004, Kultura $w$ Polsce lokalnej - w mikroskopie i przez lunete, „Kultura Współczesna”, nr 4.

Burszta Wojciech, 2008, Świat jako więzienie kultury. Pomyślenia, PIW, Warszawa.

Czerwiński Marcin, 1965, Uwagi krytyczne o socjologii kultury, „Kultura i Społeczeństwo”, nr 3.

Czerwiński Marcin 1985, Kultura i jej badanie, Ossolineum, Wrocław.

Dawydow Jurij, 1962, Rabota $i$ swoboda, Moskwa.

Dawydow Jurij, 1966, Iskusstwo i elita, Moskwa.

Dawydow Jurij, 1971 [1968], Sztuka jako zjawisko socjologiczne. Przyczynek do charakterystyki pogladów estetyczno-politycznych Platona i Arystotelesa, tłum. Krzysztof Pomian, Państwowy Instytut Wydawniczy, Warszawa.

Dubin Boris, 2008, Granicy i problemy socyotogii kultury w sowriemiennoj Rossii, „Wiestnik obszczestwiennogo mnienia", nr 5 [Lewada-Centrum, Moskwa].

Fabiś Piotr, 2008, Emile Durkheim jako teoretyk kultury, Wydawnictwo Poznańskie, Poznań.

Filipow Aleksander, 2007, In memoriam. Pamiati Jurija Dawydowa, „Socyołogiczeskoje obozrenije", t. 6, nr 1.

Gliński Piotr, 2008, Socjologia polska i Polskie Towarzystwo Socjologiczne, w: Janusz Mucha, Ewa Narkiewicz-Niedbalec, Maria Zielińska (red.), Co nas łączy, co nas dzieli?, Oficyna Wydawnicza Uniwersytetu Zielonogórskiego, Zielona Góra.

Goban-Klas Tomasz, 1972, O zadaniach i zatożeniach badań nad uczestnictwem kulturalnym, „Kultura i Społeczeństwo”, nr 2.

Grad Jan, Kaczmarek Urszula, 1999, Organizacja i upowszechnianie kultury w Polsce. Zmiany modelu, Wydawnictwo UAM, Poznań.

Gudkow Lew, 2004, Niegatiwnaja idienticznost' (1997-2002), Moskwa.

Jadow Władimir (red.), 1998, Socyotogija w Rossii, Moskwa.

Ionin Leonid, 1995, Osnowy socyokulturnogo analiza, Moskwa.

Jankowski Dzierżymir, 1991, Zróżnicowane rozumienie upowszechniania kultury i jego wspótczesna wykładnia, w: Janusz Gajda (red.), Wspótczesne dylematy upowszechniania kultury, UMCS, Lublin.

Jawłowska Aldona, 1993, Kierunki zmiany kulturowej i jej konsekwencje spoteczne, w: Andrzej Rychard, Michał Federowicz (red.), Społeczeństwo w transformacji, IFiS PAN, Warszawa. 
Kłoskowska Antonina, 1964, Kultura masowa. Krytyka i obrona, PWN, Warszawa, Kłoskowska Antonina, 1981, Socjologia kultury, PWN, Warszawa.

Kogan Lew, 1998, Issledowanija kultury $w$ paradigmie kulturnoj komunikacii, w: Władimir Jadow (red.), Socyołogija w Rossii, Moskwa.

Lewada Jurij (red.), 1993, Sowietskij prostoj czełowiek. Opyt socyalnogo portrieta na rubieże 90-ch, Mirowoj okiean, Moskwa.

Lewada Jurij, 2004, Od mnienii k ponimaniju, Lewada-Centrum, Moskwa.

Łapin Nikołaj, Ludmiła Beliajewa (red.), 2006, Socyo-kulturnyj portriet regiona, Moskwa.

Milczarek Krystyna, 1997, Kultura zideologizowana — kultura skomercjalizowana. Dylematy nauki i praktyki społecznej, „Kultura i Społeczeństwo, nr 3.

Mateckaja Anastasja, Samygin Siergiej (red.), 2007, Socyołogija kultury, Feniks, Rostow-na-Donu.

Mołda Sławomir, Skrzypczak Bohdan, 2003, Ośrodek Kultury i Aktywności Lokalnej. W poszukiwaniu modelu instytucji społecznościowej, Wydaw. Centrum Wspierania Aktywności Lokalnej CAL, Warszawa.

Sogomonow Aleksandr, 1998, Socyołogija kultury: tieorieticzeskij aspiekt, w: Władimir Jadow (red.), Socyologija $w$ Rossii, Moskwa.

Sułkowski Bogusław, 1972, Powieść i czytelnicy. Społeczne warunkowanie zjawisk odbioru, PWN, Warszawa.

Sułkowski Bogusław, 1995, Eksperyment w dziedzinie uspołecznienia kultury, „Kultura i Społeczeństwo", nr 1.

Sztompka Piotr, 2000, Trauma wielkiej zmiany. Spoteczne koszty transformacji, ISP PAN, Warszawa.

Tischner Józef, 1993, Nieszczęsny dar wolności, Znak, Kraków.

Tyszka Andrzej, 1971, Uczestnictwo w kulturze. O różnorodności stylów życia, PWN, Warszawa.

Tyszka Andrzej, 1987, Interesy $i$ ideaty kultury. Struktura społeczeństwa $i$ udziat $w$ kulturze, PWN, Warszawa.

Zinowiew Aleksander, 1986, Homo sovieticus, Paladin Grafton Books, London.

\section{STUDIES ON CULTURE IN THE TIMES OF COMMUNIST POLAND AND THE USSR AND A FRESH LOOK AT CULTURE IN THE POLISH AND RUSSIAN SOCIOLOGIES AFTER THE FALL OF COMMUNISM}

\section{Summary}

The author analyses a history of research on culture in communist Poland and the USSR (later Russian Federation). She finds similarities and differences. During the time of communist Poland a tendency was to standardize the supply of culture and make the access to it more democratic. The basic task of the sociology of culture in communist Poland was to control the advancement process of culture dissemination and research into the various forms of participation. However, in the second half of the 70s attention was more and more focused on the directions of cultural sociology development and functions. Following the fall of communism this discipline was faced with a challenge of embracing all the important directions of changes while indicating a now socio-cultural model at the same time. In the USSR, on the other hand, the government was interested only in the cultural research which was to confirm a hypothesis on fast 
cultural development of masses. Sociology of culture did not exist as a science, though Following years of deep crisis, when perestroika period began, sociologists of post soviet Russia faced a serious challenge: how to move from "the only one true" Marxist paradigm to the mastering and usage of various theories which functioned in sociology around the world. The Author indicated the contribution in this respect i.a. of Vladimir Yadov or academics circled around Yurij Levada. In general one can say that in Poland as well as in Russia, the sociology of culture following the fall of communist regime and following certain major political, economic, social and cultural changes, found itself in entirely new reality.

\section{Key words/słowa kluczowe}

Polish People's Republic / PRL; USSR / ZSRR; sociology of culture after the political change / socjologia kultury po przełomie ustrojowym 